\title{
Standardization and unification of algorithms of organizational and technical solutions in the process of performance of licensable activities
}

\author{
Vladimir Burovtsev ${ }^{1, *}$, Anatoliy Davydov ${ }^{1}$, and Alexey Dementev ${ }^{1}$ \\ ${ }^{1}$ Siberian Transport University, Dusi Kovalchuk st., 191, 630049, Novosibirsk, Russia
}

\begin{abstract}
An indispensable prerequisite for achieving the strategic objectives of the development of Russian railway complex is to strictly ensure the security of the licensable activities. At the same time, one of the main reserves for improving the economic efficiency of the transport industry will be the organization of a full competitive environment in the transport services market, creating opportunities for the implementation of the entrepreneurial initiative, and reducing the level of administrative barriers in this sphere. In this regard, the goal of scientific research is of a great urgency. This goal is to develop a set of coordinated measures of state regulation that can create conditions for the full development of the transport services market in conditions of regulating business activity in the process of carrying out licensable types of activities. The achievement of this goal is possible by the methods of institutional analysis of the administrative regulations for the provision of a state service for licensing of the activities, as well as by forming complex programs for the interaction of regulators on the basis of emerging synergistic effects. The presented paper reflects the main results of analysis and synthesis of organizational and technical solutions for the performance of licensable activities in railway transport. The results of the research are intended to contribute the improvement of the efficiency of modern state governance mechanisms in solving key problems in the development of the railway transport industry.
\end{abstract}

\section{Introduction}

The key to the successful development of the transport complex in Russia at the current stage of development is the condition for achieving a balance between the two key parameters of the state regulation vector: the level of encumbrance of the conditions for carrying out business activities in transport and the mandatory security of the functioning of the transport complex [4,7]. Transport Licensing Institute is characterized by strict regulation of the three following activities of transport service market participants:

1) Transportation of passengers;

2) Transportation of dangerous goods;

3) Loading and unloading of dangerous goods.

\footnotetext{
* Corresponding author: BurovtsevVV@mail.ru
} 
In this regard, the tasks of standardization, unification and typing in the process of analysis and synthesis of organizational and technical solutions for the performance of licensable types of transport activity become very important. We are talking about the formation of unified and coordinated methodological approaches in the process of organizing the licensing institute of transport companies' activity in order to develop a fullfledged transport services market in highly monopolized segments of the railway transport industry $[2,3]$.

\section{Methods of research}

The achievement of this goal is expedient taking into account the provisions of the new institutional economic theory, namely, the study of the concepts of "institution", "transaction" and "transaction costs" relating to classical objects of scientific research in the economic theory of transport. In particular, a significant scientific interest is paid to the study of possibilities of applying the methods of institutional analysis of the administrative regulation of the provision of a state service for licensing activities, as well as the following formation of complex programs of interaction of regulators based on the emerging synergistic effects $[5,6]$.

The production of licensable activities is strictly regulated by mandatory conditions and licensing requirements, and also by the sequence of execution of the algorithm for the provision of a state service for licensing activities. The process of obtaining a license includes a number of important steps that characterize the procedure for making organizational and technical decisions, and is summarized below (Figure 1).

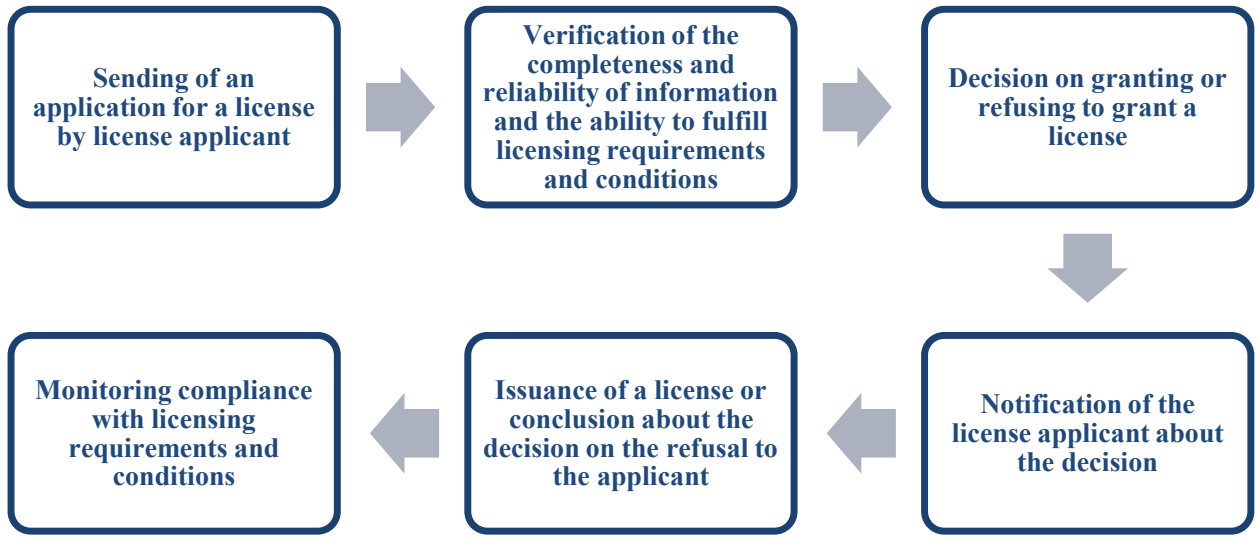

Fig. 1. Operational diagram of the process of licensing the activity.

1. The initial stage in the algorithm for the functioning of the institute for licensing the activities of railway transport enterprises is the stage of sending the application to grant a license to perform the licensable activity by the license applicant. The Regulation on the licensing of activities for the transportation of passengers by railway transport, approved by Resolution of the Government of the Russian Federation of March 21, 2012 № 221, reflects: "To obtain a license, the license applicant submits to the licensing authority an application and documents, as well as copies of:

a) documents confirming the presence on the right of ownership or other legal basis of a railway rolling stock that meets the established requirements, intended for the transportation of passengers, depending on the type of work (services) provided for in paragraph 3 of this Regulation. At the same time, the vehicle with a crew rental agreement 
is submitted with an appendix of the list of numbers of the railway rolling stock intended for the transportation of passengers and indicating the data on the composition of the crew assigned to the vehicle and its qualification;

b) the order on the organization of a specialized emergency response unit or the relevant agreement with specialized third-party organizations;

c) the appointment order for the employee responsible for the organization of passenger transportation;

d) documents on education, qualification and length of work in the relevant specialty of the employee responsible for the organization of passenger transportation;

e) documents confirming the presence in the state of the license applicant of employees providing passengers transportation and associated with the train traffic. They also should pass advanced training and certification in the prescribed manner;

f) the appointment order for the employee responsible for ensuring the safety of the traffic and operation of the rolling stock, recording of traffic accidents and their analysis, including the causes of the occurrence" [13].

It is important to note that when the licensee intends to perform new work (to provide new services) that constitute the licensable activity, the application for renewal of the license also specifies the information contained in the documents (copies of documents) that confirm the licensee's compliance with the license requirements when performing work (providing services) which the licensee intends to perform (provide).

2. The second stage in the algorithm of the functioning of the licensing institute is the verification of completeness and reliability of the information provided by the applicant, as well as the ability to meet mandatory requirements and conditions of licensing. As follows from the Regulations: "When checking the information contained in the application and documents submitted by the license applicant (licensee) and the compliance of the license applicant (licensee) with licensing requirements, the licensing authority requests the information necessary for the provision of public services in the field of licensing, which are at the dispose of authorities that provide public services, authorities providing municipal services, other government authorities, local authorities or subordinated to state authorities or local authorities of organizations, in accordance with the procedure established by the Federal Law "On the organization of the provision of state and municipal services" [13].

3. The next stage in the algorithm of functioning of the licensing institute is the stage of decision-making on granting or refusing to grant a license. The implementation of licensable activity in conditions that do not meet the requirements is recognized as impossible. As follows from the postulates of the Federal Law of 04.05.2011 № 99-FZ “On licensing of certain types of activities" (hereinafter - the Federal Law on licensing): "Within a period not exceeding forty-five working days from the date of receipt of the application for a license and attached documents, the licensing authority checks the completeness and reliability of the information contained in these application and documents, including checking compliance of the license applicant with licensing requirements and takes a decision to grant a license or refuse to provide it" [14].

4. A necessary stage in the algorithm of functioning of the licensing institute is the notification of the applicant about the decision made by the licensing authority. In accordance with the provisions of the Federal Law on licensing: "The decision to grant a license or to refuse to provide it is issued by an order (instruction) of the licensing authority. If the licensing authority takes a decision to grant a license, it is issued together with the order (instruction). The order (instruction) for granting a license and a license are signed together by the head or deputy head of the licensing authority and registered in the register of licenses. The grounds for refusal to grant a license are:

- the presence of unreliable or distorted information in an application for the grant of a license and (or) attached to it documents submitted by the license applicant; 
- the discrepancy between the license applicant and the license requirements, established during the audit;

- the license applicant submits an application for a license if there is a decision regarding the license applicant for the cancellation of a previously issued license for this type of activity.

The decision of the licensing authority on refusal to grant a license or inaction of the licensing authority may be appealed by the license applicant in the manner established by the legislation of the Russian Federation. If the application for a license indicates the need to provide a license in the form of an electronic document, the licensing authority sends a license or a notice of refusal to grant a license to the licensee in the form of an electronic document signed by an electronic signature" [14].

5. The stage of the applicant's notification follows the stage of the direct granting of a license to the applicant. For the implementation of this stage, the regulatory documents in force give no more than three working days after the day of signing and registering the license by the licensing authority. It is handed to the licensee or sent to him by registered letter with recorded delivery. As follows from the Federal Law on Licensing: "In case if a decision is made to refuse to grant a license, the licensing authority should hand over to the license applicant or send him by registered letter with recorded delivery a notice of refusal to grant a license with motivated explanation of the reasons for refusal and with reference to specific provisions of regulatory legal acts and other documents that are the basis for this refusal within three working days from the date of making of this decision, or if the reason for refusal is the nonconformity of the license applicant to the licensing requirements established during the inspection, the details of the license applicant verification act" [14].

6. The stage of control over compliance with mandatory requirements and conditions of licensing completes the algorithm for the functioning of the institute for licensing the activities of railway transport enterprises. In accordance with the requirements of regulatory acts, the licensing control is carried out in accordance with the procedure provided for by the Federal Law "On the protection of the rights of legal entities and individual entrepreneurs when implementing state control (supervision) and municipal control", taking into account the specifics of organization and conduction of inspections established by the Federal Law on Licensing.

The scheme of functioning of the licensing institute described above makes it possible to determine the methodology for algorithmization of the licensing process for railway transport enterprises that implement licensable activities in direct connection with the stages of the administrative procedures for the functioning of the licensing institute.

\section{Results of the study}

The development of the standard algorithm of the process of purposeful institutional organization of licensing the activities of railway transport enterprises consists of the following stages (Figure 2).

The process of algorithmization of a purposeful institutional organization for licensing the activities of railway transport enterprises, taking into account the target component, conforms to the classical principles and includes the following:

- formulation of the problem;

- definition of the goals of the institutional organization of licensing;

- formation and implementation of a purposeful organizing action;

- determination of the results of the organizational action on the process of institutional organization of licensing;

- an assessment of the level of achieving the goals of the organization of licensing institute on railway transport. 
- Determination of the problem of functioning of the licensing institute. The problem is characterized by a low degree of adequacy of the adopted regulatory solutions aimed at ensuring expedient conditions for the implementation of licensable activities

Stage 1

- The goals and tasks of management are formulated. The goal of the management is to increase the efficiency of the institutional organization of licensing. To achieve the goal, it is necessary to form the optimal control action, which is formed taking into

Stage 2 account the possibilities of interacting regulators

- The control action is formed. As a result of ensuring effective interaction of regulators, an effective control action is created with regard to the institutional organization of

Stage 3 licensing

- The control action is realized. As a result of the regulatory actions, the characteristics

Stage 4

of the institution for licensing the activities of transport market entities are changed

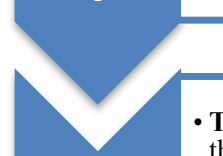

- The parameters of the internal environment of the object are changed. Changes in the characteristics of the institution of licensing entail a change in economic effects

Stage 5 arising from its functioning

- The parameters of the external environment of the object are changed. The change in the economic effects of the licensing institution ensures a change in the state of Stage 6 institutional factors of functioning of the business environment

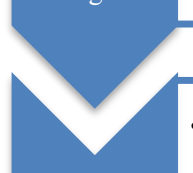

- The results of the control action are formed. The change in institutional factors entails a change in the level of transaction costs of market participants, and therefore Stage 7 determines the level of efficiency of interaction between regulators

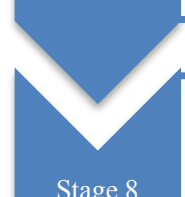

- Assessment of the efficiency of interaction. It is possible to measure the level of transaction costs, characterizing the degree of effectiveness of controlling the efficiency Stage 8 of interaction of regulators

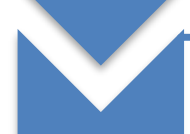

- Monitoring and control. As a result of monitoring the level of transaction costs, control of its permissible parameters is carried out, a decision is made on presence or absence of Stage 9 a problem of interaction between regulators

Fig. 2. Stages of development of the algorithm for analyzing and synthesizing organizational and technical solutions for the performance of licensable activities $[6,7]$. 
In this case, the algorithm for analyzing, searching for solutions, and developing practical programs for the interaction of adjacent regulators in the process of institutional organization of licensing of the activities of transport market entities, regardless of the projected scenarios for economic development, will be characterized by the following actions.

1. The determining factor in the organization of purposeful interaction of aggregated entities in the context of inter-agency electronic interaction is the formation of a general vector of state regulation - its goal-setting. This vector is formed at the higher strategic level of management and is reflected in the strategic, fundamental documents of the development of railway transport and the macroeconomic system as a whole. Examples of such documents can be programs of structural transformation of the railway complex, its development strategies, scenario plans and road maps, formed in the strategic planning horizon.

2. The key to the success of managerial decisions regarding the institutional organization of licensing the activities of railway transport enterprises, including in the context of interagency electronic interaction, is a systematic analysis of the problems that need to be solved in order to achieve the above-mentioned general goals. It is necessary to emphasize the system-forming character of this stage; it is not so much about particular cases of a problem nature, as about their totality, which makes it possible to classify their systemic character.

3. Analysis of problems from the general to the particular, while sets and subsets of lower profile, concretizing the previous level, are identified from the main problems of a general nature. Therefore, the problem area in the structural dynamics in the process of detailing takes the form of a truncated pyramid. The upper part of this pyramid will be represented by problems which are generalized, complex, and include the series of subproblems of different levels. The lower part of this pyramid will have a wide base and is represented by an array of problems that are constructive and concretized.

4. Specification and refinement of the parameters of the problem state in conditions of interdepartmental electronic interaction is carried out until the level of the simplest and indivisible applied problems is reached. Therefore, the entire array describing the problem area reaches the maximum possible elementary level, which does not allow us to consider the problem area in a more detailed state than the already achieved level of specification. The possibility of definitive statement of a specific problem for each of the elementary problems arises at this problem level.

5. At this stage, each of the selected elementary problems synthesizes the optimal solution, defines an authorized macro regulator able to perform the synthesized solution, including in the conditions of inter-agency electronic interaction. The reached specified level allows one to unambiguously understand the task and to formulate an optimal solution as clearly as possible. The same complexity of the elementary tasks also simplifies the process of optimizing the choice of solutions.

6. Associated sets of applied solutions form solution complexes depending on a single problem. There is a kind of asymmetric relation of the generalization process of synthesized solutions to the array of problem areas. The key factor at this stage is a clear connection between the complexity of the problem and the sets of solutions.

7. Synthesized complexes of decisions form the programs of interaction of aggregated subjects of management of the process of institutional organization of licensing of the activities of railway transport enterprises. These programs are synchronized in time and amounts of consumed administrative resources.

Therefore, the implementation of this algorithm provides for the possibility of encompassing the entire procedure - from assessment of system problems to implementation of applied tasks to solve them. The final and key stage in the 
implementation of this algorithm is the formation of complex programs of interaction between regulators in the process of institutional organization of licensing the activities of railway transport enterprises.

\section{Standardization of state service on licensing the activities: institutional analysis}

"Standardization is the activity to establish norms, rules and characteristics in order to ensure:

- safety of products, works and services for the environment, life, health and property;

- technical and information compatibility, as well as interchangeability of products;

- the quality of products, works and services in accordance with the level of development of science, engineering and technology; uniformity of measurements;

- saving of all types of resources; security of economic facilities, taking into account the risk of natural and man-made disasters and other emergencies;

- the defense capability and mobilization readiness of the country" [1, p. 7].

The goal of standardization is to achieve a high degree of ordering of activities in the field of licensing and regulating railway transport through the widespread and continuous application of statutory regulations, requirements and standards for the implementation of tasks of current and planned period in the field of licensing the activities of transport market entities. In the conditions of market relations, standardization implements institutional functions regulating the economic, social and communicative components of the licensing process for railway transport enterprises, which proved out by the prevailing domestic practice and world experience [8-12]. In view of the foregoing, it is advisable to conduct an institutional analysis of the standardization process of the licensing institute in railway transport (table 1).

Table 1. Institutional analysis of the content and functions of the state service for licensing the activities of railway transport enterprises (The analysis is based on the study of the standard of administrative regulations for public services in the field of railway transport).

\begin{tabular}{|l|l|l|l|}
\hline \multicolumn{1}{|c|}{$\begin{array}{c}\text { Section of administrative } \\
\text { regulations }\end{array}$} & \multicolumn{1}{|c|}{ Essential content } & $\begin{array}{c}\text { Institutional } \\
\text { function }\end{array}$ & \multicolumn{1}{|c|}{$\begin{array}{c}\text { Costs of transport } \\
\text { services market entities }\end{array}$} \\
\hline Name of state service & $\begin{array}{l}\text { Identification of state } \\
\text { service }\end{array}$ & Communicative & $\begin{array}{l}\text { There are no conditions } \\
\text { for the emergence of } \\
\text { costs }\end{array}$ \\
\hline $\begin{array}{l}\text { Name of the federal public } \\
\text { authority that provides the public } \\
\text { service }\end{array}$ & $\begin{array}{l}\text { Identification of } \\
\text { operator }\end{array}$ & Communicative & $\begin{array}{l}\text { There are no conditions } \\
\text { for the emergence of } \\
\text { costs }\end{array}$ \\
\hline $\begin{array}{l}\text { Description of the result of } \\
\text { provision of public service }\end{array}$ & $\begin{array}{l}\text { Defines the form and } \\
\text { content of the document }\end{array}$ & Social & $\begin{array}{l}\text { There are no conditions } \\
\text { for the emergence of } \\
\text { costs }\end{array}$ \\
\hline $\begin{array}{l}\text { Term for provision of public } \\
\text { service }\end{array}$ & $\begin{array}{l}\text { Defines the total time } \\
\text { interval that } \\
\text { characterizes the } \\
\text { irrational costs of the } \\
\text { user of public service }\end{array}$ & Economic & $\begin{array}{l}\text { Irrational transaction } \\
\text { costs }\end{array}$ \\
\hline $\begin{array}{l}\text { List of regulatory and legal acts } \\
\text { regulating relations arising in } \\
\text { connection with provision of } \\
\text { public service }\end{array}$ & $\begin{array}{l}\text { Defines the institutional } \\
\text { base for the process of } \\
\text { provision and use of } \\
\text { public services }\end{array}$ & Communicative & $\begin{array}{l}\text { There are no conditions } \\
\text { for the emergence of } \\
\text { costs }\end{array}$ \\
\hline $\begin{array}{l}\text { An exhaustive list of documents } \\
\text { for provision of public service to } \\
\text { be provided by the user of the } \\
\text { public service }\end{array}$ & $\begin{array}{l}\text { Defines the workflow } \\
\text { from the user of public } \\
\text { service }\end{array}$ & Economic & $\begin{array}{l}\text { Rational transaction } \\
\text { costs }\end{array}$ \\
\hline
\end{tabular}




\begin{tabular}{|c|c|c|c|}
\hline $\begin{array}{l}\text { An exhaustive list of documents } \\
\text { for the provision of public } \\
\text { service, which are at the disposal } \\
\text { of the federal public authority and } \\
\text { which the user has the right to } \\
\text { submit }\end{array}$ & $\begin{array}{l}\text { Defines } \\
\text { interdepartmental } \\
\text { workflow }\end{array}$ & Communicative & $\begin{array}{l}\text { There are no conditions } \\
\text { for the emergence of } \\
\text { costs }\end{array}$ \\
\hline $\begin{array}{l}\text { An exhaustive list of reasons for } \\
\text { refusing to accept user documents }\end{array}$ & $\begin{array}{l}\text { Defines the } \\
\text { requirements for the } \\
\text { format of the package } \\
\text { of consumer documents }\end{array}$ & Economic & $\begin{array}{l}\text { Regulatory transaction } \\
\text { costs }\end{array}$ \\
\hline $\begin{array}{l}\text { An exhaustive list of reasons for } \\
\text { suspending or refusing to provide } \\
\text { a public service }\end{array}$ & $\begin{array}{l}\text { Defines the factors that } \\
\text { impede the provision of } \\
\text { public service }\end{array}$ & Economic & $\begin{array}{l}\text { Irrational transaction } \\
\text { costs }\end{array}$ \\
\hline $\begin{array}{l}\text { List of additional services that are } \\
\text { necessary and mandatory for the } \\
\text { provision of public service }\end{array}$ & $\begin{array}{l}\text { Defines the actions of } \\
\text { adjacent, interacting } \\
\text { operators }\end{array}$ & Social & $\begin{array}{l}\text { There are no conditions } \\
\text { for the emergence of } \\
\text { costs }\end{array}$ \\
\hline $\begin{array}{l}\text { The procedure, amount and } \\
\text { grounds for levying a state fee or } \\
\text { other fee charged for the } \\
\text { provision of public services }\end{array}$ & $\begin{array}{l}\text { Defines the regulatory } \\
\text { costs of users of public } \\
\text { service }\end{array}$ & Economic & $\begin{array}{l}\text { Regulatory transaction } \\
\text { costs }\end{array}$ \\
\hline $\begin{array}{l}\text { Maximum waiting time for the } \\
\text { user of public service in the queue }\end{array}$ & $\begin{array}{l}\text { Defines the time loss of } \\
\text { the user of public } \\
\text { service }\end{array}$ & Economic & $\begin{array}{l}\text { Irrational transaction } \\
\text { costs }\end{array}$ \\
\hline $\begin{array}{l}\text { The term and procedure for } \\
\text { registration of the application and } \\
\text { documents of the user of public } \\
\text { service }\end{array}$ & $\begin{array}{l}\text { Defines the cost of user } \\
\text { and operator interaction }\end{array}$ & Economic & $\begin{array}{l}\text { Irrational transaction } \\
\text { costs }\end{array}$ \\
\hline $\begin{array}{l}\text { Requirements for premises in } \\
\text { which a public service is } \\
\text { provided, a place of waiting and } \\
\text { information }\end{array}$ & $\begin{array}{l}\text { Defines the physical } \\
\text { conditions of use of } \\
\text { public service }\end{array}$ & Communicative & $\begin{array}{l}\text { There are no conditions } \\
\text { for the emergence of } \\
\text { costs }\end{array}$ \\
\hline $\begin{array}{l}\text { Indicators of availability and } \\
\text { quality of public services }\end{array}$ & $\begin{array}{l}\text { Defines parameters for } \\
\text { monitoring the process } \\
\text { of providing and using } \\
\text { public service }\end{array}$ & Social & $\begin{array}{l}\text { There are no conditions } \\
\text { for the emergence of } \\
\text { costs }\end{array}$ \\
\hline $\begin{array}{l}\text { Other requirements for interaction } \\
\text { in electronic form }\end{array}$ & $\begin{array}{l}\text { Defines additional } \\
\text { parameters of electronic } \\
\text { workflow }\end{array}$ & Communicative & $\begin{array}{l}\text { There are no conditions } \\
\text { for the emergence of } \\
\text { costs }\end{array}$ \\
\hline
\end{tabular}

\section{Main conclusions}

Institutional analysis of the content and functions of the public service for licensing the activities of railway transport enterprises confirms that in conditions of market relations, standardization performs institutional functions, predetermining opportunities to reduce the level of transaction costs of participants of transport services market.

Therefore, the development of methodological approaches to standardization and algorithmization of the mechanism of institutional organization of licensing is to identify new opportunities for ordering the process of licensing through a broad and continuous use of the methodology of institutional analysis of the conditions for the emergence of transaction costs, the use of unified algorithmic approaches of state regulation, based on a standardized regulatory base that forms the institutional environment of railway transport enterprises $[6,7]$.

\section{References}

1. G.D. Krylova, Fundamentals of standardization, certification, and metrology: Textbook for universities (UNITY-DANA, 2006) 
2. Federal Law № 210-FZ of July 27 (2010)

3. Federal Law № 184-FZ of December 27 (2002)

4. A.V. Annenkov, Organization of production and management of the transport company in the conditions of competition in the transport market (RGOTUPS, 2003)

5. U.A. Ataev, Formation of the organizational and economic mechanism of licensing development in market conditions: author's abstract (Makhachkala, 2004)

6. V.V. Burovtsev, Transport business of Russia 4, 66-67 (2012)

7. V.V. Burovtsev, Transport business of Russia 4(119), 79-84 (2015)

8. E.V. Gritsenko, Organization of the provision of public services as a way of solving issues of local significance: Russian and European experience, Public services: legal regulation (Russian and foreign experience): collection of papers (Walters Kluwer, 2007)

9. T.Yu. Maslennikova, Organizational and methodological foundations of control of licensable activities in transport: author's abstract (St. Petersburg, 1997)

10. A.V. Muzychenko, Economic and Legal Bulletin 4, 40-59 (2004)

11. S.V. Palkin, The World of Transport 5(54), 202-208 (2014)

12. B. Shavans, Economic issues 6, 4-21 (2003)

13. Government Decree of the Russian Federation of 21.03.2012 № 221

14. Federal Law № 99-FZ of May, 4 (2011) 